\title{
PHYSIOLOGICAL RESPONSES OF PEA PLANTS TO TREATMENT WITH SYNTHETIC AUXINS AND AUXIN-TYPE HERBICIDE
}

\author{
Dessislava Todorova ${ }^{1}$, Iskren Sergiev* ${ }^{* 1}$, Elena Shopova ${ }^{1}$, Liliana Brankova ${ }^{1}$,

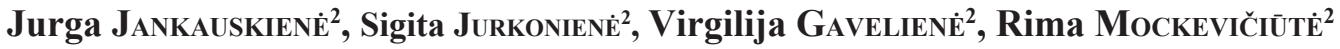 \\ ${ }^{1}$ Bulgarian Academy of Sciences, Institute of Plant Physiology and Genetics, Acad. G. Bonchev Str. 21, 1113 \\ Sofia, Bulgaria \\ ${ }^{2}$ Nature Research Centre, Institute of Botany, Akademijos Str. 2, 08412 Vilnius, Lithuania \\ *Corresponding author. E-mail: iskren@bio21.bas.bg
}

\begin{abstract}
Todorova D., Sergiev I., Shopova E., Brankova L., Jankauskienė J., Jurkonienė S., Gavelienė V., Mockevičiūtė R., 2021: Physiological responses of pea plants to treatment with synthetic auxins and auxin-type herbicide. - Botanica, 27(2): 125-133.

The effect of exogenously applied 2,4-D (2,4-dichlorophenoxyacetic acid) on growth and antioxidant defence of pea plants, preliminary treated with two synthetic auxin compounds 1-[2-chloroethoxycarbonyl-methyl]4-naphthalenesulfonic acid calcium salt (TA-12) and 1-[2-dimethylaminoethoxycarbonylmethyl]naphthalene chlormethylate (TA-14) was examined. All chemicals were applied by foliar spraying. Applied alone, TA-12 and TA-14 had no significant effects, but they modulated the 2,4-D induced changes on most investigated biochemical parameters. The shoot fresh weight reduction caused by 2,4-D was partially overcome by the use of TAs. The use of TAs partially overcame the shoot fresh weight reduction induced by 2,4-D. Apart from this, no significant changes were observed in the other biometric parameters. Treatment with 2,4-D did not enhance lipid peroxidation, and hydrogen peroxide content was slightly increased. These data indicate that treatment with 2,4-D did not cause severe oxidative stress, which is also confirmed by the results of the antioxidant defence system. The application of 2,4-D provoked mild accumulation of thiol-containing compounds, free proline and phenolic compounds and increased the antioxidant enzyme activities (GST, SOD, CAT, POD and GR) to a moderate degree. Pretreatment with TAs noticeably decreased the non-enzymatic antioxidants (free proline, total phenolics and total low-molecular thiols) compared to plants treated with 2,4-D only. Except for GR, TAs pretreatment returned the enzyme activities to levels close to the controls. Based on the results obtained, we suggest that the application of both synthetic auxins could modulate 2,4-D herbicide effects.
\end{abstract}

Keywords: antioxidants, growth, Pisum sativum (L.), stress markers, 2,4-D.

\section{INTRODUCTION}

The chemicals possessing herbicidal activity are more than 1500 compounds and are the most used farming products applied against weeds in agriculture worldwide (Pesticide Properties Database, 2021). The herbicides which affect all plant species are classified as total, and those which affect certain plant species are classified as selective. Regarding their mechanism of action, herbicides can be merged into four main groups: blockers of photosynthesis, inhibitors of amino acid biosynthesis, inhibitors of lipid and fatty acid biosynthesis, and auxin type herbicides.

The highly effective selective herbicide of the auxin type 2,4-dichlorophenoxyacetic acid (hereafter, 2,4-D) is applied against dicotyledonous weeds in monocotyledonous crops (COBB, 1992; PETERson et al., 2016). Formulations containing 2,4-D are manufactured in the form of more than 20 different preparations alone and in combination with other herbicides (PETERSON et al., 2016). It is mainly foliar ap- 
plied or directly into the soil as a solution or granules (Walters, 2000). Field doses of 2,4-D correspond to auxin concentrations 1000 times above the average plant concentrations. This affects the plants, resulting in hormonal imbalance and oversaturation of the systems for degradation and control of hormone levels. As a result, uncontrollable growth of susceptible plants is observed, resulting in resource depletion and death (CoBB, 1992; Walters, 2000). Although 2,4-D is not used against weeds in legumes (Fabaceae), as they are sensitive, data are demonstrating its action on pea plants (Romero-Puertas et al., 2004; McCARTHYSuÁreZ et al., 2011; PAZMiÑo et al., 2011).

The herbicidal antidotes are chemicals that can lessen to some degree or wholly overcome the phytotoxic effects of herbicides on cereals or monocotyledonous crops without reflecting on herbicide action on weeds (JABLONKAI, 2013). Although the safeners (protectors), which inactivate herbicides used in dicotyledonous crops, are underexplored (JABLONKAI, 2013), it was shown that some plant growth regulators can modulate physiological responses of herbicide treated dicotyledonous plants (Zheleva et al., 1994; Kim \& Jin, 2006; Pinol \& Simon, 2009; CuI et al., 2010; Singh et al., 2017). In our recent study (SERGIEV et al., 2020), we established that two synthetic auxin compounds, namely (1-[2-chloroethoxycarbonylmethyl]-4-naphthalenesulfonic acid calcium salt) and TA-14 (1-[2-dimethylaminoethoxycarbonylmethyl] naphthalene chlormethylate), which are structural analogues of naphthyl acetic acid (synthetic auxin), also modulated herbicide induced plant responses of young pea seedlings treated with Glyphosate (inhibitor of aromatic amino acids synthesis) and Glean-75 (inhibitor of branched amino acids synthesis). This gives a perspective for further investigations on their potential protective effect against other herbicides, like 2,4-D.

The herbicide action builds up of reactive oxygen species (hereafter, ROS) (SERGIEv et al., 2006; ROMEro-Puertas et al., 2004; McCarthy-Suárez et al., 2011; Pazmiño et al., 2011; Varshney et al., 2015; McCarthy-SuÁrez, 2017; Langaro et al., 2017), which is accompanied with significant changes in the plant antioxidant system consisting of different enzymatic and non-enzymatic ingredients. Therefore, this study aimed to investigate the physiological effects of synthetic auxins TA-12 and TA-14 on pea plant responses provoked by auxin type herbicide 2,4-D. In addition, in this study, we aimed to answer which principal components of the enzymatic and non-enzymatic defence systems are altered.

\section{MATERIALS AND METHODS}

\section{Plant material and treatments}

Pea plants (Pisum sativum L.) of the cultivar 'Ran-1' were grown hydroponically on a half-strength Hoagland-Arnon nutrient solution in phytotrons with the following characteristics: $24 / 22^{\circ} \mathrm{C}$ day and night temperatures, $12 / 12 \mathrm{~h}$ photoperiod, $150 \mu \mathrm{mol} \mathrm{m}^{-2} \mathrm{~s}^{-1}$ photon flux density.

The water solutions of $1 \mathrm{mM}$ TA-12 (1-[2-chloroethoxycarbonyl -methyl]-4-naphthalenesulfonic acid calcium salt) and TA-14 (1-[2-dimethylaminoethoxycarbonylmethyl]naphthalene chlormethylate) containing $0.01 \%$ Tween- 80 used as a surfactant were applied on 13-day-old seedlings by leaf spraying. After 24 hours, plantlets were sprayed with $0.05 \mathrm{mM}$ water solution of 2,4-D (containing $0.01 \%$ Tween-80). Biometrical and biochemical analyses were made two weeks after 2,4-D treatment.

\section{Biometrical analyses}

The length of roots and shoots was measured using a linear ruler (precision $1 \mathrm{~mm}$ ). Fresh biomass (FW) of shoots and roots was weighed on an electronic balance, precision $0.001 \mathrm{~g}$ (Precision Standard TS4000, Ohaus ${ }^{\circledR}$, USA).

\section{Biochemical analyses}

The kinetic records of enzyme activities were done on Shimadzu UV-1601 UV-Visible spectrophotometer (Shimadzu, Japan). The absorbance records were made on Multiskan Spectrum UV/VIS spectrophotometer (Thermo Fisher Scientific, Finland). All biochemical analyses were done using fresh plant material collected from $3^{\text {rd }}$ leaf pair.

Approximately $200 \mathrm{mg}$ plant biomass was ground in ice-cold potassium phosphate buffer $(100 \mathrm{mM}$, $\mathrm{pH}$ 7.0) supplied with $1 \mathrm{mM}$ ethylenediaminetetraacetic acid. Polyvinylpyrrolidone $(1 \% \mathrm{w} / \mathrm{v})$ was added to each sample. Homogenates were centrifuged for 
$30 \min \left(15000 \times g\right.$ at $\left.4{ }^{\circ} \mathrm{C}\right)$ on Sigma $2-16 \mathrm{~K}$ centrifuge. Supernatants were used for the determination of the enzyme activities of superoxide dismutase (SOD), guaiacol peroxidase (POX), catalase (CAT), glutathione reductase (GR), and glutathione S-transferase (GST). In brief, SOD activity was measured according to BEAUCHAMP \& FRIDOVICH (1971) method based on the inhibition of photochemical reduction of nitrobluetrazolium assayed at $560 \mathrm{~nm}$. One enzyme unit (EU) of SOD was defined as the enzyme quantity sufficient to provoke $50 \%$ inhibition of the nitrobluetrazolium reduction. POX activity was measured according to the method of DiAs \& COSTA (1983) using guaiacol $\left(\varepsilon=26.6 \mathrm{mM}^{-1} \mathrm{~cm}^{-1}\right)$ as an external electron donor. The increase in absorbance at $470 \mathrm{~nm}$ was recorded for $60 \mathrm{~s}$. CAT activity was monitored for $60 \mathrm{~s}$ by the hydrogen peroxide degradation at $240 \mathrm{~nm}\left(36.8 \mathrm{mM}^{-1} \mathrm{~cm}^{-1}\right)$ according to Aebi (1984) method. GR activity was measured by the reduction of 5,5'-dithiobis(2-nitrobenzoic acid) (DTNB) by glutathione and the increase in absorbance at $412 \mathrm{~nm}\left(\varepsilon=6.2 \mathrm{mM}^{-1} \mathrm{~cm}^{-1}\right)$ after SMith et al. (1988). The GST activity was determined by using 1-chloro-2,4-dinitrobenzene (CDNB) as a substrate and recorded at $340 \mathrm{~nm}\left(\varepsilon=9.6 \mathrm{mM}^{-1} \mathrm{~cm}^{-1}\right)$ according to Gronwald et al. (1987) method.

Approximately $300 \mathrm{mg}$ plant biomass was ground in $0.1 \%$ ice-cold trichloroacetic acid. The homogenates were centrifuged for $30 \mathrm{~min}\left(15000 \times g\right.$ at $\left.4^{\circ} \mathrm{C}\right)$ on Sigma 2-16K centrifuge. Supernatants were used to determine stress biomarkers (malondialdehyde (MDA), hydrogen peroxide $\left(\mathrm{H}_{2} \mathrm{O}_{2}\right)$ and free proline), and water-soluble antioxidants (free thiol-containing compounds and soluble phenols). Content of MDA was determined according to KRAMER et al. (1991) method as a product of membrane phospholipid peroxidation reaction using thiobarbituric acid-reagent $\left(\varepsilon=155 \mathrm{mM}^{-1} \mathrm{~cm}^{-1}\right)$. Hydrogen peroxide content was measured after AlEXIEVA et al. (2001) and calculated by a standard curve. The derivatisation assay with acid ninhydrin according to BATES et al. (1973) method and reading the absorbance at $520 \mathrm{~nm}$ was used to determine the free proline amount. The concentration of thiol-containing compounds was determined spectrophotometrically at $412 \mathrm{~nm}$ using Ellman's reagent (ElLman, 1959). The content of total soluble phenolics was determined by incubation of the supernatant with Folin-Ciocalteu reagent, and the reaction mix- ture was measured at $725 \mathrm{~nm}$ (SwAIN \& GoldsteIn, 1964). The data were calculated by using gallic acid (GA) as a standard.

\section{Statistical analyses}

Three independent experiments with three internal replicates were done. The data presented in the Figures were statistically analysed by Duncan's multiple range test $(p<0.05)$ and are mean values \pm Standard error (SE).

\section{RESULTS}

The 2,4-D treatment reduced by $29 \%$ only fresh weight of pea shoots, while no significant alterations were found in the rest biometrical parameters measured (Fig. 1).

The pretreatment with TAs compounds mitigated the reduction of shoot biomass accumulation. The synthetic auxins provoked a slight increase in shoot length (by 8\%) and gathered fresh weight (by 13\% and $18 \%$, respectively) of roots after single treatments. In addition, both TAs compounds applied alone did not cause any significant changes in the level of biochemical parameters analysed (Fig. 2 and Fig. 3) compared to control ones. However, 2,4-D application reduced MDA quantity by $27 \%$ below the control (Fig. 2A). MDA content remained lower than the control in 2,4-D + TAs-treated plants also.

A significant increase (by 106\%) of free proline content after 2,4-D treatment was established (Fig. 2B). Pretreatment with TAs noticeably decreased the proline content compared to plants treated with 2,4-D only. The 2,4-D application did not alter significantly total phenolic content (Fig. 2C). The TA compounds applied before herbicide decreased the content of phenolics as compared to 2,4-D treated variant. The content of free thiol-containing compounds was also increased by $25 \%$ in plants treated with 2,4-D (Fig. 2D). The application of TA compounds decreased its content in 2,4-D-treated plants.

An increase of $\mathrm{H}_{2} \mathrm{O}_{2}$ content (by $14 \%$ ), accompanied by a rise in the activity of SOD (by $19 \%$ ), was found in the seedlings treated with 2,4-D (Fig. 3A and $3 \mathrm{~B}$ ). Conversely, the spraying with TAs before 2,4-D treatment caused a decrease in $\mathrm{H}_{2} \mathrm{O}_{2}$ quantity and SOD activity to the respective control levels. 


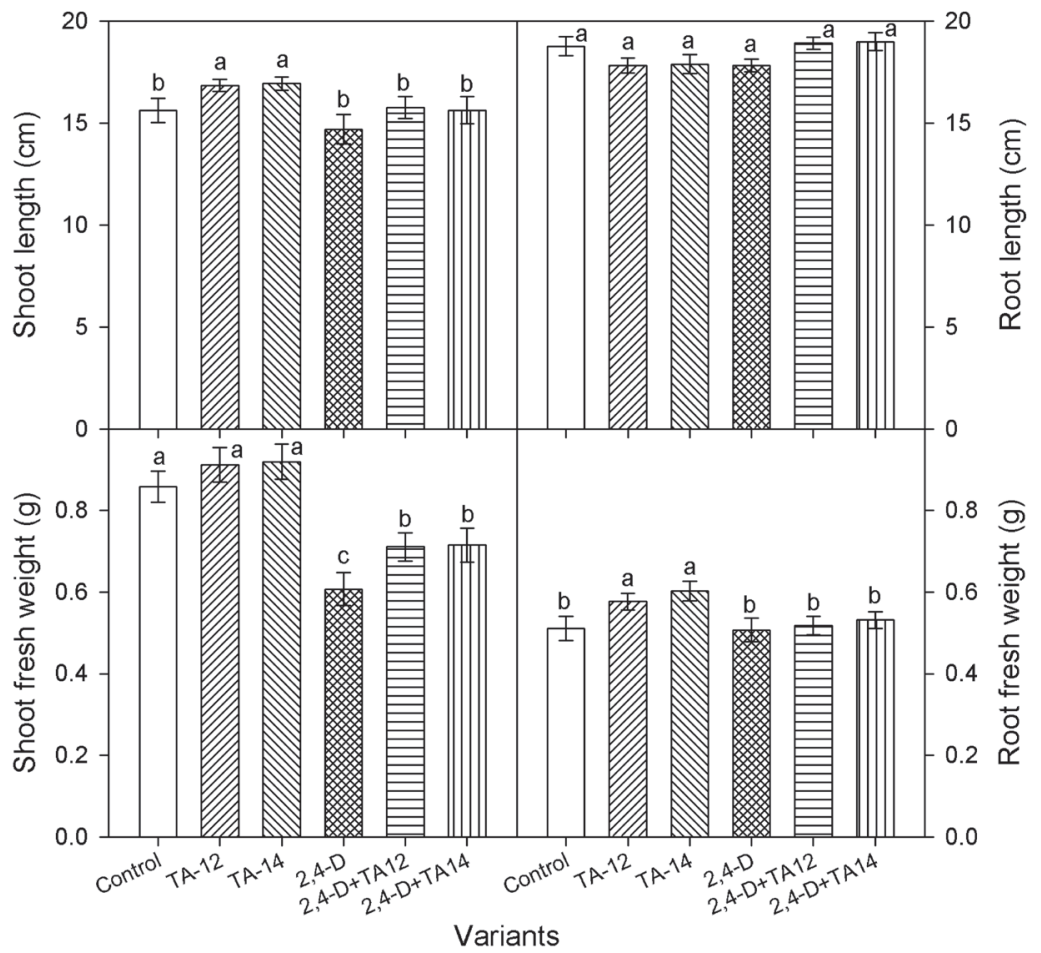

Fig. 1. Fresh weight and length of shoots and roots of garden pea plants sprayed with $1 \mathrm{mM} \mathrm{1-[2-chloroethoxycarbonyl}$ -methyl]-4-naphthalenesulfonic acid calcium salt (TA-12) or 1-[2-dimethylaminoethoxicarbonylmethyl]naphthalene chlormethylate (TA-14) and treated with herbicide 2,4-D. Data are mean values \pm SE. Different letters designate statistically significant differences at $p<0.05$

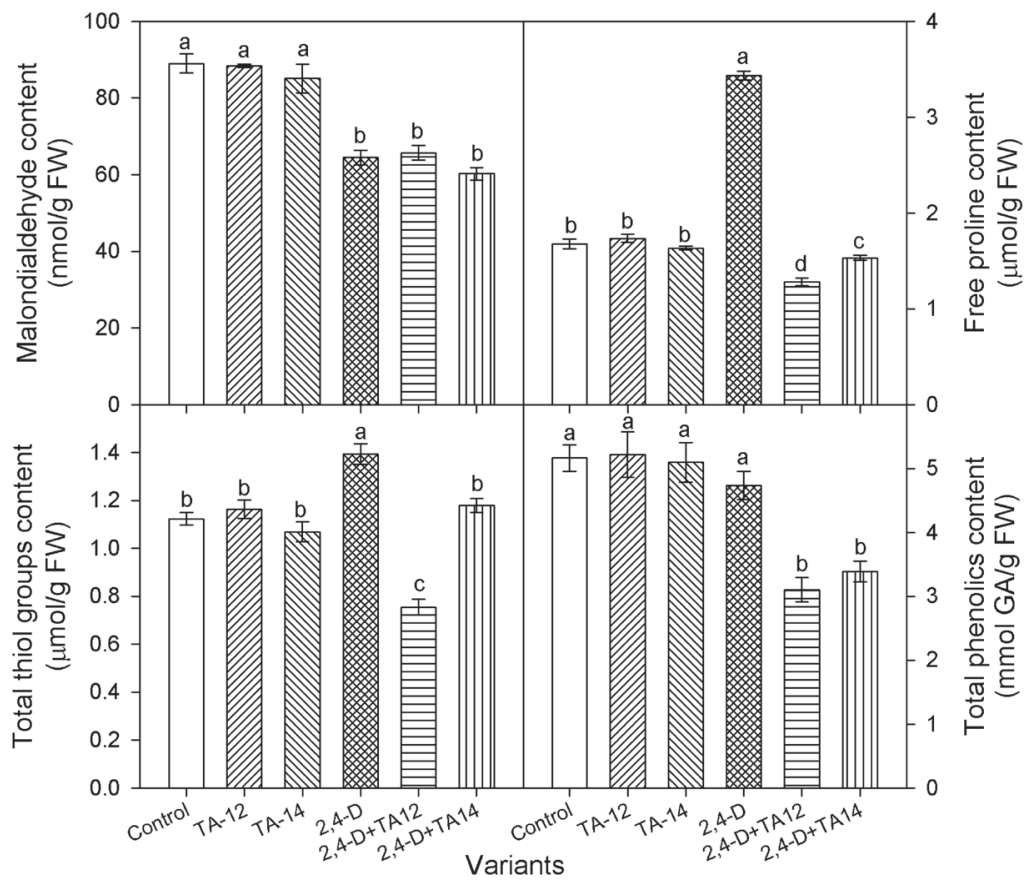

Fig. 2. Malondialdehyde, free proline, total phenolics, and total thiol-containing compounds content in leaves of garden pea plants sprayed with $1 \mathrm{mM}$ 1-[2-chloroethoxycarbonyl -methyl]-4-naphthalenesulfonic acid calcium salt (TA-12) or 1-[2-dimethylaminoethoxicarbonylmethyl]naphthalene chlormethylate (TA-14) and treated with herbicide 2,4-D. Data are mean values \pm SE. Different letters designate statistically significant differences at $p<0.05 ; \mathrm{FW}-$ fresh weight 


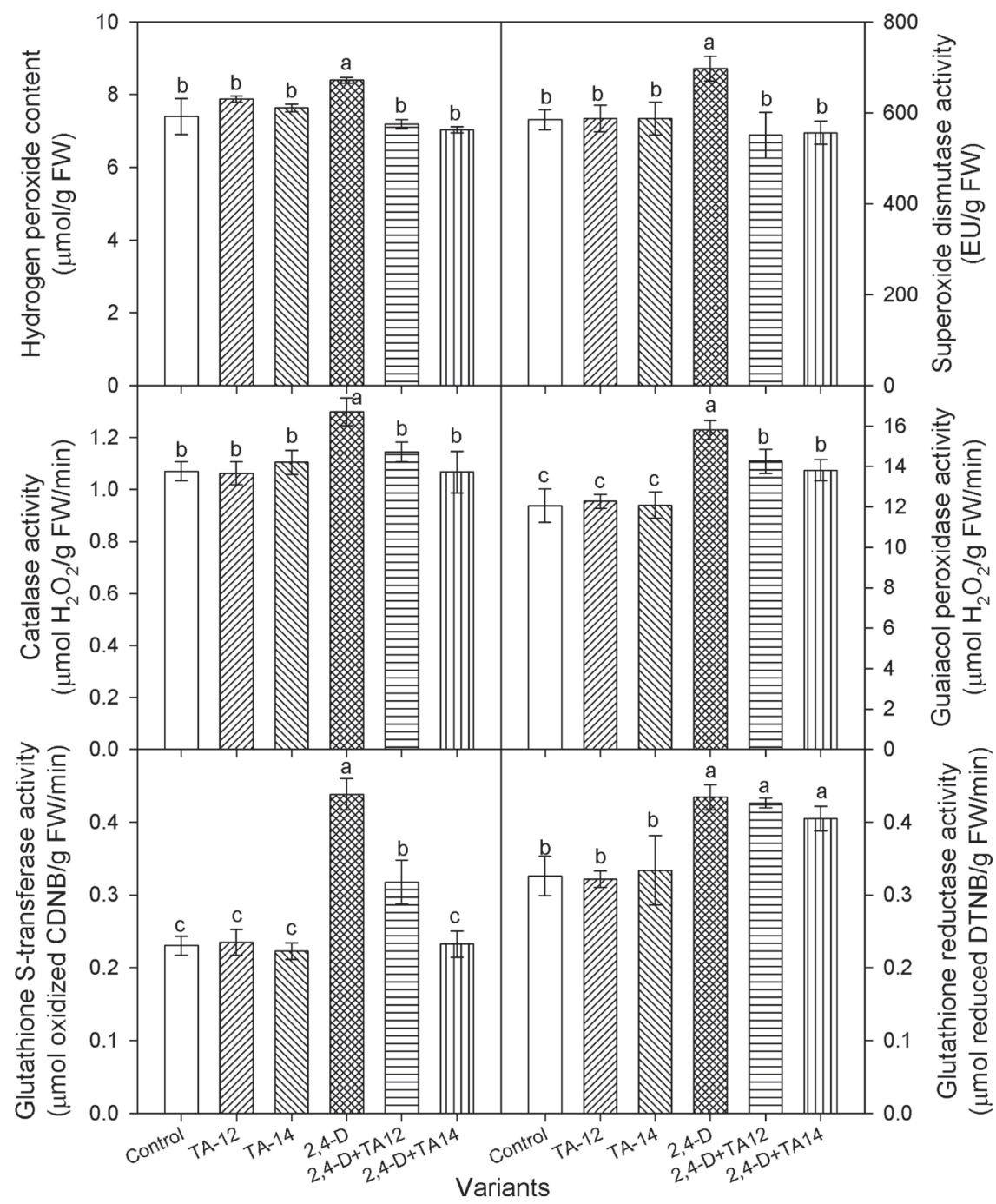

Fig. 3. Hydrogen peroxide content, and activity of superoxide dismutase, catalase, guaiacol peroxidise, glutathione S-transferase, and glutathione reductase in leaves of garden pea plants sprayed with $1 \mathrm{mM} \mathrm{1-[2-chloroethoxycarbonyl} \mathrm{-methyl]-4-nap-}$ hthalenesulfonic acid calcium salt (TA-12) or 1-[2-dimethylaminoethoxicarbonylmethyl]naphthalene chlormethylate (TA-14) and treated with herbicide 2,4-D. Data are mean values \pm SE. Different letters designate statistically significant differences at $p<0.05$; FW - fresh weight

The catalase activity was also increased by $21 \%$ after 2,4-D treatment (Fig. 3C). However, its activity was decreased to the control level in TAs + 2,4-D treated plants. Peroxidase activity (Fig. 3D) was raised by $31 \%$ after 2,4-D application, while pretreatment with TAs decreased the POX activity.

The 2,4-D treatment significantly increased GST activity by $90 \%$ (Fig. 3E). The application of synthetic auxins before herbicide led to a considerable decrease in enzymatic activity. The glutathione reductase activity (Fig. 3F) was increased by $33 \%$ and did not alter in plants pretreated with TAs.

\section{DISCUSSION}

The extensive use of herbicides in modern agricultural practice often impacts weeds and non-target crops. Despite their different mode of action, a common feature of all herbicides is bringing on oxidative stress in plants due to increased generation of ROS (VARShNEY et al., 2015; McCARTHY-SuÁrez, 2017; LANGARO et al., 2017). ROS can cause harm to key primary metabolites such as proteins, lipids, carbohydrates, and DNA that disrupts plant growth and even lead to plant death. 
Although it is known that the molecular mechanism of action of 2,4-D is habitualdisruption of the hormonal equilibrium, which disturbs normal plant growth (Walters, 2000; Romero-Puertas et al., 2004; PAZMIÑo et al., 2011), in our study, pea growth was not affected significantly by 2,4-D application, except fresh shoot weight. It could be due to the lower concentration we used than those applied in other investigations (Romero-Puertas et al., 2004; PazMIÑo et al., 2011). Furthermore, the herbicide did not cause accumulation of MDA, and hydrogen peroxide content was increased to a minor degree. So, probably oxidative stress did not occur in 2,4-D treated plants or was not so severe. Two possible explanations could arise: 1) the used concentration was subherbicide and did not provoke oxidative events, or 2) specific components of antioxidant defence were strongly activated to detoxify 2,4-D injuries. Plants develop a complex of antioxidant ROS-scavenging systems to cope with oxidative stress, including enzymatic and non-enzymatic antioxidants (GOMES et al., 2014; Varshney et al., 2015; de Freitas-Silva et al., 2017). Concerning the amounts of non-enzymatic antioxidants, we established that while total phenolics content did not alter significantly, the quality of the rest non-enzymatic antioxidants - thiol-containing compounds (glutathione in particular) free proline was increased noticeably by 2,4-D treatment. Regarding the activity of enzymatic antioxidants, we found that they were increased to a different extent (ranging from 19\%to 33\%) by herbicide application, especially that of GST, which was raised almost twice.

Obviously, most of the components of the antioxidant machinery were substantially activated by the herbicide application, but predominantly those involved in 2,4-D detoxification and metabolism. It has been proven that 2,4-D detoxification is realised by direct conjugation with glucose and amino acids (Peterson et al., 2016) and conjugation to glutathione by GSTs (Edwards \& Dixon, 2005). Phenoxyacetic herbicides like 2,4-D form amino acid conjugates through bonding to sugars and amino acids (mainly aspartate and glutamate). The conjugation with amino acids is more prevalent in sensitive plants like dicotyledonous species (PETERSON et al., 2016). Based on the significantly increased content of free proline in our study, the possible role of proline as a direct 2,4-D detoxifier could not be excluded. In addition, Verma et al. (2010) have also reported a substantially increased amount of proline in 2,4-D treated pea plants.

Increased content of thiol-containing compounds (glutathione, which represents more than $95 \%$ of non-protein thiols), along with the amplified activity of GST in 2,4-D treated pea plants appear to be particularly important in maintaining the leaf metabolic homeostasis. Glutathione is involved in the oxidative stress responses by 1) direct scavenging of ROS and/ or by 2) detoxifying herbicides and other xenobiotics (reviewed in Katerova \& Miteva, 2010). As a critical component of the glutathione-ascorbate shuttle (Halliwell-Asada cycle), it regulates the redox state within the plant cells where during the ROS deactivation, it is oxidised. Then the enzyme GR converts back the oxidised glutathione to reduced form (reviewed in Katerova \& Miteva, 2010). Glutathione can detoxify xenobiotics due to their conjugation by the enzyme family GSTs (Edwards \& Dixon, 2005). Several distinct classes of plant GSTs are recognised. Among them, tau (T) and phi (F) classes are the most prominent groups that are involved in the detoxification of herbicides (LABRou et al., 2015). In addition to $\mathrm{T}$ and $\mathrm{F}$ glutahione S-transferases, lambda (L) class plant GSTs are auxin-inducible (MARss, 1996; VAN DER Kop et al., 1996; SHI et al., 2014). Increased GST activity in leaves of pea plants exposed to 2,4-D correlated with its involvement in the conjugation of 2,4-D with glutathione, leading to decreased herbicide levels in plant cells. In accordance, some studies suggest that GST can be strongly induced during the treatment with 2,4-D herbicide (ROMERO-PUERTAS et al., 2004; PAZmiño et al., 2011). In our study, pea plants responded to 2,4-D by increasing the synthesis of proline and glutathione and raising GST activity.

As it was mentioned, the application of some PGRs could modulate endogenous plant defence systems to better counteract ROS and oxidative stress due to herbicide treatment. Therefore, our study investigated the effects of synthetic auxins as modulators of action of 2,4-D in pea plants. Preliminary application of TA compounds to herbicide treated plants overcame the decrease of fresh biomass of pea shoots. In the plants treated with 2,4-D, MDA level did not change extensively by preliminary application of both TA compounds. It remained low along with 
the content of hydrogen peroxide and SOD activity. However, the content of non-enzymatic antioxidants (free proline, total phenolics and total low-molecular thiols) was substantially decreased in conjunction with a reduction in catalase, POX, and GST activity in TAs+2,4-D treated plants as compared to 2,4-D treated only. Only GR activity was not altered in plants preliminary treated with TA compound, following our earlier study with Glyphosate and Glean75 (Sergiev et al., 2020). This could mean that both auxin analogues can trigger pea adaptation reactions to 2,4-D application by modulating its physiological and metabolic processes, which finally led to better shoot growth. Our results represent a reasonable basis for further investigation on the possibility for modulation of herbicide action by applying synthetic auxins.

\section{ACKNOWLEDGEMENTS}

This study was supported by the Bulgaria-Lithuania joint research programme of the Bulgarian Academy of Sciences (2019-2021).

\section{REFERENCES}

Aebi H., 1984: Catalase in vitro. - Methods of enzymology, 105: 121-126. https://doi.org/10.1016/s0076-6879(84)05016-3

Alexieva V., Sergievi., Mapelli S., KaranovE., 2001: The effect of drought and ultraviolet radiation on growth and stress markers in pea and wheat. Plant, Cell \& Environment, 24: 1337-1344. https://doi.org/10.1046/j.1365-3040.2001.00778.x

Bates L., Waldren R., Teare I., 1973: Rapid determination of free proline for waterstress studies. - Plant and Soil, 39: 205-207. https://doi.org/10.1007/BF00018060

Beauchamp C., Fridovich I., 1971: Superoxide dismutase: Improved assay and an assay applicable to acrylamide gels. - Analytical Biochemistry, 44: 276-287. https://doi.org/10.1016/0003-2697(71)90370-8

CoвB A., 1992: Herbicides and plant physiology. London.

Cui J., Zhang R., Wu G.L., Zhu H.M., Yang H., 2010: Salicylic acid reduces napropamide toxicity by preventing its accumulation in rapeseed
(Brassica napus L.). - Archives of Environmental Contamination and Toxicology, 59: 100-108. https://doi.org/10.1007/s00244-009-9426-4

de Freitas-Silva L., Rodríguez-Ruiz M., Houmani H., Campos da Silva L., Palma J.M., CorPAS F.J., 2017: Glyphosate-induced oxidative stress in Arabidopsis thaliana affecting peroxisomal metabolism and triggers activity in the oxidative phase of the pentose phosphate pathway (OxPPP) involved in NADPH generation. Journal of Plant Physiology, 218: 196-205. https://doi.org/10.1016/j.jplph.2017.08.007

Dias M.A., Costa M.M., 1983: Effect of low salt concentrations on nitrate reductase and peroxidase of sugar beet leaves. - Journal of Experimental Botany, 34: 537-543. https://doi.org/10.1093/jxb/34.5.537

EdwARdsR.,DixonD.P.,2005:PlantGglutathionetransferases. - Methods in Enzymology, 401: 169-186. https://doi.org/10.1016/s0076-6879(05)01011-6

Ellman G., 1959: Tissue sulfhydryl groups. - Archives of Biochemistry and Biophysics, 82: 70-77. https://doi.org/10.1016/0003-9861(59)90090-6

Gomes M.P., Smedbol E., Chalifour A., HénaultEthier L., Labrecque M., Lepage L., Lucotte M., Juneau P., 2014: Alteration of plant physiology by glyphosate and its by-product aminomethylphosphonic acid: an overview. - Journal of Experimental Botany, 65(17): 4691-4703. https://doi.org/10.1093/jxb/eru269

Gronwald J.W., Fuerst E.P., Eberlein C.V., EGLI M.A., 1987: Effect of herbicide antidotes on glutathione content and glutathione S-transferase activity of sorghum shoots. - Pesticide Biochemistry and Physiology, 29: 66-76. https://doi.org/10.1016/0048-3575\%2887\%2990085-X

JABLONKAI I., 2013: Herbicide safeners: effective tools to improve herbicide selectivity. - In: Price A., Kelton J. (eds), Herbicides - current research and case studies in use: 589-620. - London. https://doi.org/10.5772/55168

Katerova Z., Miteva L., 2010: Glutathione and herbicide resistance in plants. - In: ANJUM N., Chan M.T., Umar S. (eds), Ascorbate-glutathione pathway and stress tolerance in plants: 191-207.Dordrecht-Heidelberg-London-New York. https://doi.org/10.1007/978-90-481-9404-9_6

KIM H.S., JIN C.D., 2006: Polyamines as anti- 
oxidant protectors against paraquat damage in radish Raphanus sativus L. cotyledons. - Journal of Plant Biology, 49: 237-246. https://doi.org/10.1007/BF03030539

Kramer G., Norman H., Krizek D., Mirecki R., 1991: Influence of UV-B radiation on polyamines, lipid peroxidation and membrane lipids in cucumber. - Phytochemistry, 30: 2101-2108. https://doi.org/10.1016/0031-9422(91)83595-C

Labrou N.E., Papageorgiou A.C., Pavli O., FlemetaKISE.,2015:PlantGSTome:structureandfunctional role in xenome network and plant stress response.Current Opinion in Biotechnology, 32: 186-194. https://doi.org/10.1016/j.copbio.2014.12.024

Langaro A.C., Agostinetto D., Ruchel Q., GarCiAJ.R.,PerboniL.T., 2017: Oxidativestresscaused by the use of preemergent herbicides in rice crops.Revista Ciência Agronômica, 48(2): 358-364. https://doi.org/10.5935/1806-6690.20170041

MARrS K.A., 1996: The functions and regulation of glutathione S-transferases in plants. - Annual Review of Plant Physiology and Plant Molecular Biology, 47: 127-158. https://doi.org/10.1146/annurev.arplant.47.1.127

McCARTHy-SuÁrez I., 2017: Role of reactive oxygen species in auxin herbicide phytotoxicity: current information and hormonal implications - are gibberellins, cytokinins, and polyamines involved? - Botany, 95(4): 369-385. https://doi.org/10.1139/cjb-2016-0084

McCarthy-Suárez I., Gómez M., del Río L.A., PalMAJ.M.,2011:Role of peroxisomes in the oxidative injuryinducedbytheauxinherbicide2,4-Dinleaves of pea plants. - Biologia Plantarum, 55: 485-492. https://doi.org/10.1007/s10535-011-0114-7

Pazmiño D.M., Rodríguez-Serrano M., Romero-Puertas M.C., Archilla-Ruiz A., Del Río L.A., Sandalio L.M., 2011: Differential response of young and adult leaves to herbicide 2,4-dichlorophenoxyacetic acid in pea plants: role of reactive oxygen species. Plant, Cell \& Environment, 34: 1874-1889. https://doi.org/10.1111/j.1365-3040.2011.02383.x

Pesticide Properties Database, 2021: University of Hertfordshire. Pesticide Properties Database http://sitem.herts.ac.uk/aeru/ppdb/en/atoz.htm [accessed 8 October 2021].

Peterson M.A., McMaster S.A., Riechers D.E., Skel-
TONJ.,StahlmanP.W.,2016:2,4-Dpast, present, and future:AReview.-Weed Technology,30:303-345. https://doi.org/10.1614/WT-D-15-00131.1

PIÑOL R., SimÓn E., 2009: Effect of 24-epibrassinolide on chlorophyll fluorescence and photosynthetic $\mathrm{CO}_{2}$ assimilation in Vicia faba plants treated with the photosynthesis inhibiting herbicide terbutryn.Journal of Plant Growth Regulation, 28: 97-105. https://doi.org/10.1007/s00344-008-9077-0

Romero-Puertas M.C., McCarthy I., Gómez M., Sandalio L.M., Corpas F.J., Del Río L.A., Palma J.M., 2004: Reactive oxygen speciesmediated enzymatic systems involved in the oxidative action of 2,4-dichlorophenoxyacetic acid. - Plant, Cell \& Environment, 27: 1135-1148. https://doi.org/10.1111/j.1365-3040.2004.01219.x

Sergiev I.G., Alexieva V.S., Ivanov S.V., Moskova I.I., Karanov E.N., 2006: The phenyl urea cytokinin 4PU-30 protects maize plants against glyphosate action. - Pesticide Biochemistry and Physiology, 85: 139-146. https://doi.org/10.1016/J.PESTBP.2006.01.001

Sergiev I., Todorova D., Shopova E., Brankova L., JankauskienĖ J., JuRkonienĖ S., Gaveliené V., MockevičIŪtė R., 2020: Assessment of synthetic auxin-type compounds as potential modulators of herbicide action in Pisum sativum L. - Biologia, 75(11): 1845-1853. https://doi.org/10.2478/s11756-020-00557-0

Shi H.-Y., LiZ.-H., Zhang Y.-X., Chen L., Xiang D.-Y., Zhang Y.-F., 2014: Two pear glutathione S-transferases genes are regulated during fruit development and involved in response to salicylic acid, auxin, and glucose signaling. - PLoS ONE, 9(2): e89926. https://doi.org/10.1371/journal.pone.0089926

Singh H., Singh N.B., Singh A., Hussain I., 2017: Exogenous application of salicylic acid to alleviate glyphosate stress in Solanum lycopersicum. - International Journal of Vegetable Science, 23(6): 552-566. https://doi.org/10.1080/19315260.2017.1347845

Smith I.K., Vierheller T.L., Thurne C.A., 1988: Assay of glutathione reductase in crude tissue homogenates using 5,5'-dithiobis(2-nitrobenzoic acid). - Analytical Biochemistry, 175: 408-413. https://doi.org/10.1016/0003-2697(88)90564-7

Swain T., Goldstein J.L., 1964: The quantitative analyses of phenolic compounds. - In: PRID- 
HAM J.B. (ed.), Methods in polyphenol chemistry: 131-146. - Oxford-London-Edinburgh-New York- Paris-Frankfurt.

van der Kop D.A.M., Schuyer M., Scheres B., van DER ZAAL B.J., HoOYKAAs P.J.J., 1996: Isolation and characterization of an auxin-inducible glutathione S-transferase gene of Arabidopsis thaliana. - Plant Molecular Biology, 30: 839-844. https://doi.org/10.1007/BF00019016

Varshney S., Khan M.I.R., Masood A., Per T.S., Rasheed F., Khan N.A., 2015: Contribution of plant growth regulators in mitigation of herbicidal stress.Journal of Plant Biochemistry \& Physiology, 3: 160. https://doi.org/10.4172/2329-9029.1000160
Verma Y., Gupta G.N., LaKshman K.S., 2010: Effect of 2, 4-Dichlorophenoxyacetic acid on growth and oxidative metabolism of pea (Pisum sativum L.) plant. - The Allahabad Farmer, 65(2): 84-89.

WALTERS J., 2000: Environmental fate of 2,4-dichlorofenoxyacetic acid. Environmental monitoring and pest management. Department of Pesticide Regulation, Sacramento, CA 95814-3510. http://citeseerx.ist.psu.edu/viewdoc/download?d oi $=10.1 .1 .639 .4289 \&$ rep $=$ rep1\&type $=$ pdf

Zheleva D., Tsonev T., Sergiev I., KaraNOV E., 1994: Protective effect of exogenous polyamines against atrazine in pea plants. - Journal of Plant Growth Regulation, 13: 203-211. https://doi.org/10.1007/BF00226038

\section{FIZIOLOGINE் ŽIRNIŲ REAKCIJA İ SINTETINIŲ AUKSINŲ IR AUKSINŲ TIPO HERBICIDO POVEIKI}

\section{Dessislava Todorova, Iskren Sergiev, Elena Shopova, Liliana Brankova, Jurga Jankauskienė, Sigita Jurkoniené, Virgilija GaVelienĖ, Rima Mockevičıūtė}

\section{Santrauka}

Ištirtas egzogeninis 2,4-dichlorofenoksiacto rūgšties (2,4-D) herbicido poveikis žirnių, apdorotų dviem sintetiniais auksinų analogais (TA-12 ir TA14), augimui ir antioksidaciniam aktyvumui. Cheminėmis medžiagomis buvo apipurkšti žirnių lapai. Panaudoti atskirai, TA-12 ir TA-14 junginiai neturèjo reikšmingo poveikio augalams, tačiau panaudoti kartu su 2,4-D, jie moduliavo 2,4-D sukeltas biochemines reakcijas. Panaudojus TA junginius, pavyko iš dalies ịveikti 2,4-D sukeliamą ūglių žaliosios masès mažejjimą. Taip pat nebuvo nustatyta kitu augalų biometrinių parametrų pokyčių. Paveikus žirnius 2,4-D, nedaug padidejo vandenilio peroksido kiekis, bet lipidu peroksidacija nesustiprèjo. Gauti duomenys rodo, kad 2,4-D stipraus oksidacinio streso ne- sukèlè. Tą patvirtino ir antioksidantinio aktyvumo tyrimo rezultatai. Augalus apdorojus 2,4-D, truputi padidèjo tiolio turinčių junginių, laisvojo prolino ir fenolinių junginių kaupimasis ir vidutiniškai padidèjo antioksidacinių fermentų (GST, SOD, CAT, POD ir GR) aktyvumas. Apdorojus augalus TA junginiais, pastebimai sumažejjo nefermentinių antioksidantu (laisvojo prolino, bendrojo fenolių ir bendrojo mažos molekulinès masės tiolių) kiekiai, palyginti su augalais, kurie buvo paveikti tik 2,4-D. Antioksidaciniu fermentų aktyvumas išliko artimas fermentų aktyvumui, nustatytam kontrolès sąlygomis (išskyrus GR). Remdamiesi gautais rezultatais darome prielaidą, kad naudojant abu sintetinius auksinus galima moduliuoti 2,4-D herbicido poveikị. 